\title{
Fordulat az Európai Unió elektronikus kormányzat politikájában
}

A huszonegyedik század hajnalán Magyarország fejlődési útját egy 25 tagállamból álló konglomerátum határozza meg, amely grandiózus terveket sző a világban betöltött vezető szerep megszerzésére. A tanulmány szerzője megállapítja, hogy az elektronikus kormányzati aktivitás terén mutatkozó csökkenő ütemű fejlődés Európa döntéshozóit az eddigi irányvonal átértékelésére késztette. Az elektronikus ügyintézés megvalósításában a tagállamok között tapasztalható különbségek a nemzetek fölötti politika erőit arra sarkallják, hogy a széttöredezettség helyett egységes politikai állásfoglalások és konkrét programok végrehajtása mellett szálljanak síkra. Kérdés azonban, hogy sikerül-e a saját kultúrával, identitással, ezeréves gyökerekkel és hagyományokkal rendelkező nemzetállamokat elkötelezetté tenni az információs társadalom ügye mellett.

\section{Szerzői információ:}

Juhász Lilla

Az ELTE Állam-és Jogtudományi Kar, Politológia szakán végzett 2003-ban. Jelenleg a Budapesti Műszaki Egyetem Információ- és Tudásmenedzsment Tanszéken egyetemi tanársegéd, illetve a BME - UNESCO Információs Társadalom-és Trendkutató Központ kutatója. Emellett Leonardo pályázat bíráló, s a Gyermek-, Ifjúsági- és Sportminisztérium mobilitási szakértôje.

Így hivatkozzon erre a cikkre:

Juhász Lilla. „Fordulat az Európai Unió elektronikus kormányzat politikájában”.

Információs Társadalom IV, 2. szám (2004): 79-89.

$\Longrightarrow$ https://dx.doi.org/10.22503/inftars.IV.2004.2.5

A folyóiratban közölt müvek

a Creative Commons Nevezd meg! - Ne add el! - Így add tovább! 4.0

Nemzetközi Licenc feltételeinek megfelelően használhatók. 
J u h á s z L i 11 a

\section{Fordulat az Európai Unió elektronikus kormányzat politikájában}

\section{Az elektronikus kormányzat kialakulásának gyökerei}

Az Európai Unió elektronikus kormányzatának megszületését a nemzetek feletti politikai hatalom megszerzésére és a gazdasági pozíció tekintetében a világelsőség kivívására irányuló törekvések hívták életre. A megvalósítás útján az első mérföldkövet jelentố, Lisszabonban megfogalmazott prioritásokban az a grandiózus cél jelenik meg, hogy Európának 2010-ig a legversenyképesebb tudásalapú társadalommá kell válnia. Az e-kormányzat bölcsőjének tehát a lisszaboni csúcstalálkozó tekinthetô, hiszen a világviszonylatban elismert vezető szerep megszerzéséhez mindenekelốtt gazdasági és szociális kohézióra, valamint a modernizáció alapfeltételének számító fejlett közszolgáltatásokra, vagyis a regionális, nemzetállami és nemzetek fölötti szintű bürokrácia korszerúsítésére és egyszerüsítésére van szükség. Ennek felismerése az eurokraták gondolatvilágában fokozatosan egyre nagyobb teret kapott: az információs társadalom építésének alappilléreit jelentô eEurope dokumentumokban az online közszolgáltatások kiépítése eleinte még csak egy volt a számos kulcsfontosságúként megnevezett feladat között, a jelenleg is hatályos eEurope2005 akciótervben azonban már az öt legfóbb prioritás között szerepel.

1. ábra

Az e-kormányzat felépítése az Európai Unióban ${ }^{1}$

Politikai kontextus

Liszaboni csúcs eEurope Belsố Piac Európai állampolgárság

Bővítés Biztonság és stabilitás Európa világban betöltött helye

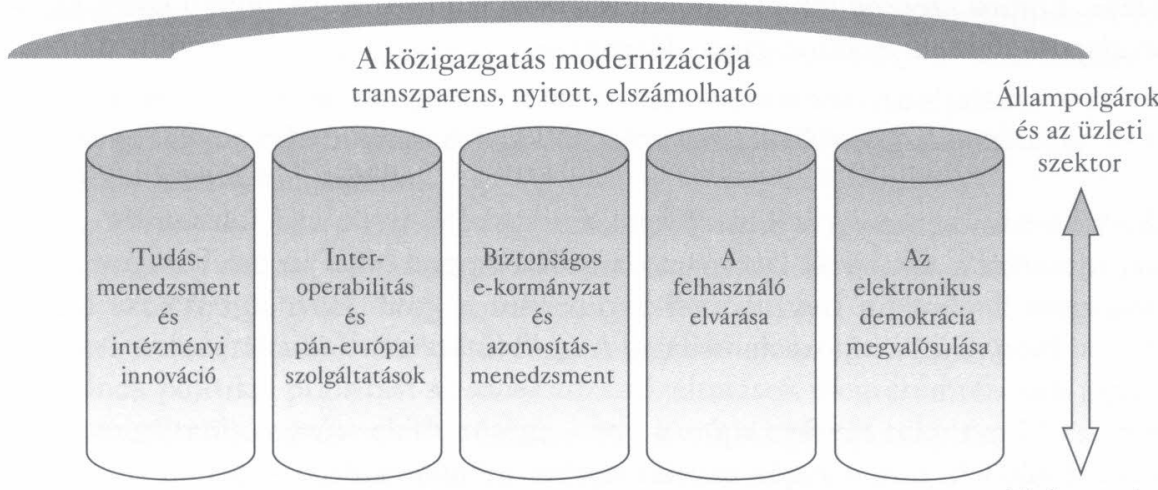

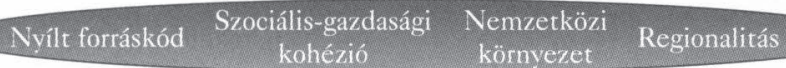

közigazgatás

'eGovernment Research \& Development

http://europa.eu.int/information_society/programmes/egov_rd/focus/index_en.htm 
Ebben a tanulmányban arra keresek választ, hogy mely tényezốk megléte befolyásolja az elektronikus kormányzat fejlődésének irányvonalát és milyen elvek mentén építi fel stratégiáját az Unió, majd azokat a politikai, társadalmi és gazdasági okokat vizsgálom, amelyeknek következtében egyes tagállamok az e-kormányzati fejlôdés éllovasaivá váltak.

\section{Paradigmaváltás és az e-kormányzati fejlesztési programok alapiát képező meta-szint}

Napjainkban paradigmaváltás zajlik az e-kormányzat területén is. A nemzetek fölötti szint a figyelôszolgálatok, az ún. felkészültségi (readiness) vizsgálatok, a fejlôdést nyomon követô elemzések, valamint különféle hatásvizsgálatok révén naprakész információkkal rendelkezik arról, hogy az Európai Unióban milyen a tagállamok felkészültségi állapota, az elôző évekhez képest hogyan alakult a fejlődés üteme, és az állampolgárok mely szolgáltatások használatát preferálják. A kutatások eredményei megmutatják az e-kormányzati fejlődés irányvonalát is. Az 1. ábra bemutatja az e-kormányzat jelenlegi felépítését, ami a gazdasági, társadalmi és államigazgatási fejlődés során alakult ki: a nyílt forráskódú információs- és kommunikációs technológiákra épülő új közigazgatás a regionális, nemzetállami, nemzetek fölötti, valamint nemzetközi kihívásoknak egyaránt meg kíván felelni. Ez a modell a szolgáltatóoldali (back office) folyamatok szintjén gyökeres szervezeti átalakulásokat jelent, az állampolgárok körében a huszonegyedik század információs múveltségének elterjedését eredményezi, a szociális és gazdasági kohézió révén segíti a demokratizálódási folyamatok felerôsödését és a közigazgatás felhasználóközpontú rendszerét hozza létre.

Az elektronikus kormányzat itt bemutatott többrétegú jelentéstartalmának kulcsa a kutatásban és a fejlesztésben, valamint az innovációban rejlik. Az implementáció sikerességét az úgynevezett „legjobb gyakorlatok” (best practices) elterjedését biztosító politikai kontextus határozza meg, ami olyan tényezôkból áll össze, mint az egységes piac, a határok nélküli Európa, a gyarapodás, a stabilitás és a biztonság megteremtése, Európa szerepének megerősítése a világszínpadon, valamint a közös identitáson alapuló európai állampolgárság létrejötte. 
2. ábra

Az e-kormányzat megvalósításában szerepet játszó tényezốk ${ }^{2}$

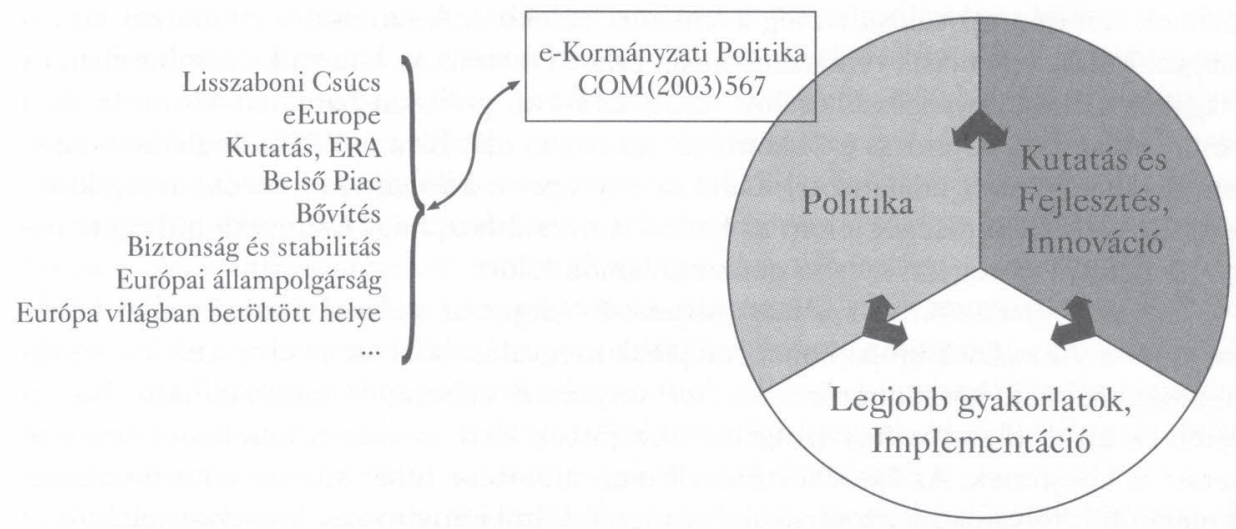

Megállapítható, hogy az elektronikus kormányzatot meghatározó politikai kontextus és az e-kormányzat megvalósitása terén az Európai Unió komoly gondokkal küszködik. Írásom célja ennek a tételnek a bizonyítása és az online közigazgatás kialakítása mögött megbúvó „mélyrétegek” feltárása a bemutatott ábrák segítségével, azok kibontásával.

A politikai irányvonal töredezettségére 2003 nyarán Antonio Alabau professzor hívta fel a figyelmet: az Európai Unió e-kormányzati tevékenységeiért két különböző főigazgatóság és négy ügyosztály felel, ami lehetetlenné teszi az egységes, nemzetek fölötti szintű e-kormányzat kialakítását. A megvalósítás egyrészt a tagállamok közigazgatási rendszerein belül (back office) megnyilvánuló passzív ellenállás következtében, másrészt az ügyféloldali (front office) szolgáltatások nem kielégítő minősége, valamint az állampolgári érdeklődés hiánya miatt nem sikerül.

Az online Európa megteremtése elő́tt álló akadályok felismerése - azok leküzdése érdekében - az Európai Unió döntéshozóit újabb és újabb állásfoglalásokra és felülvizsgálatokra készteti. Ezeket kétféle rendszerszinten mutatom be: egyrészt az absztrakciós szintet veszem górcsố alá, és az e-kormányzat megteremtésének „miért"-jeit vizsgálom, majd azokat az alapelveket veszem szemügyre, amelyeknek a gyakorlatba való átültetése elengedhetetlen a célok eléréséhez. Az általam vizsgált dokumentumokból az e-kormányzati fejlôdés irányvonalainak meghatározásához az alábbi feladatsor látszik kirajzolódni:

„Szorosabbra fogni a gyeplöt”, hogy összehangolt akciók és egységes politikai állásfoglalások szülessenek. Az Európai Unió fragmentált e-kormányzati aktivitása, a koherens politika hiánya azt eredményezi, hogy a tervezett e-kormányzati programok megvalósulása csupán a nemzetállamok akaratától függ. A tagállamok azonban különbözó mértékben rendelnek politikai prioritást az online közszolgáltatások megteremtésének ügyéhez, s így a szolgáltatások online elérhetôsége - ami Európa egészét tekintve 72 és 15 százalék között mozog - tagállamonként erősen változó képet mutat. A különbségek arra

\footnotetext{
${ }^{2}$ Paul Timmers: eGovernment Policy and the EU. Public Administrations Conference, Naples, Italy, 22
} November 2003 
figyelmeztetnek, hogy a nemzetek fölötti szinten nem elégséges egy általános akcióterv, emellett konkrét lépéseket, több célt és prioritást kell meghatározni, fokozni kell az országok közötti információcserét, és az Uniónak ellenőriznie kell, hogy a tagállamok szintjén mi valósult meg a kitúzött célokból. A szorosabb ellenốrzés látens megvalósulása egy másik rendszerszinten érhetô tetten. Az Unió a Luxemburgban és Hágában aláírt „Egységes Okmány” kibocsátásával politikai hatalmat követelt, és a nemzetállami szuverenitás csökkentését irányozta elô. Ez a nyílt állásfoglalás a tagállamok ellenállásával találkozott. Ezért az egységes e-kormányzati tevékenység kifejlesztése újabb lehetőséget jelent az Unió számára ahhoz, hogy észrevétlenül egyre nagyobb befolyásra tegyen szert a nemzetállamok fölött.

Az alulról jövó (bottom-up) kezdeményezések támogatása, a demokráciahiány elleni küzdelem jegyében. Az online Európa koncepciójának megvalósulásában az elkészült cselekvési programoknak köszönhetốen számos területen előrelépés tapasztalható, hiszen újabb és újabb elektronikus szolgáltatások jöttek létre, amelyek munkahelyteremtô hatást is kifejtenek. Az összeköttetések megteremtése tehát sikeresnek tekinthető. A megindult folyamatok azonban alapvetốen felülrôl irányítottak (top-doren jellegúek) és nem egészültek ki bottom-up kezdeményezésekkel, és az állampolgári kereslet sem követte a kínálatot, ami szükségképpen az addigi e-kormányzati irányvonal felülvizsgálatához vezetett, hiszen az online közszolgáltatások és a dinamikus e-gazdasági környezet megteremtésének sikere - ami a szélessávú hozzáférésen, a versenyképes árakon és a biztonságos infrastruktúrán alapul - elképzelhetetlen a keresleti oldal közremúködése nélkül. A politika kialakításában tehát ettôl a ponttól kezdve egyrészt nagyobb szerepet kapnak a civil szerveződések és a nem-kormányzati szervezetek, másrészt elvárható a tagállamok és a regionális politikai szereplők még szorosabb és tudatosabb elkötelezettsége az online kormányzati szolgáltatások mellett.

A digitális szakadék ellen és a társadalmi-gazdasági kohézió megteremtéséért folyó harc. Míg az elektronikus kormányzat fejlesztéséhez szükséges programok végrehajtásának útját álló valamennyi tényező - köztük a fent említett néhány súlyos akadály is - vertikális természetû, azaz mindenütt jelen van, addig a digitális szakadék problémája horizontálisan metszi át Európát, és bizonyos régiókban, társadalmi csoportokban fokozottan érvényesül. A nemzetek fölötti szint egyre nagyobb ellenőrzési és beavatkozási lehetőségek megszerzésére törekszik, a szubvencionálást szorgalmazva a kiegészítő támogatások, valamint a regionális és helyi kezdeményezések közös csatornákba terelése mellett száll síkra, és a hátrányos helyzetű csoportok érdekeit szolgáló akciók programját tűzi zászlajára. A regionális, illetve lokális szféra az Unió fontos szövetségese lett a nemzetállamok elleni harcban.

A nemzetek fölötti szint ilyen irányú törekvései a folyamatok Janus-arcúságára figyelmeztetnek. A nemzetállamok egyrészt a szövetséges szerepében tetszelegnek, támogatásuk nélkül ugyanis az elektronikus kormányzat megvalósítása uniós és tagállami szinten egyaránt bukásra van ítélve, másrészt azonban az állampolgárok bevonása, a demokratikus legitimáció megszerzése hosszú távon a nemzetállami szuverenitás csökkentését célozza, Brüsszel javára. 


\section{A konkrét akciók mögöt† megjelenő irányelvek}

Az Európai Unió e-kormányzati tevékenységének fősodrát az imént ismertetett három irányelv követése alkotja, ami elsósorban az alábbi területeken nyilvánul meg:

A tudásmenedzsment és a intézményi szintú úitások együttmüködése, a back office folyamatok modernizációjának jegyében. Az Unió célja a köztisztviselők hatékony motivációja és irányítása, tudásuk és kreativitásuk mobilizálása annak érdekében, hogy bürokratikus mentalitásukat ügyfélközpontú szemlélet váltsa fel a közigazgatás egész szervezetrendszerében. Ennek eléréséhez a felesleges adminisztrativ korlátok megszüntetését célzó intézkedésekre van szükség, és elkerülhetetlen a munkafolyamatok egészének reformja, valamint az információ megosztása valamennyi szint között. Az elektronikus kormányzat sikere szempontjából tehát kulcsfontosságú prioritás a szolgáltatóoldal intézményi és gondolkodásmódbeli változása, melynek eredményeként információs múveltséggel és információfeldolgozási készségekkel felvértezett közigazgatási apparátus áll majd az állampolgárok rendelkezésére.

Interoperabilitás és páneurópai szolgáltatások. A kormányzati hálózatok közötti kölcsönös együttmúködés és a múködôképes integrált rendszerek megteremtése nélkül a páneurópai dimenzióban nem beszélhetünk e-kormányzati folyamatokról. Az integrációt a technológia oldaláról kizárólag a nyílt forráskódú szoftverek használata biztosítja, ezért az Unió döntéshozói messzemenőkig támogatják ezek széles körben történô elterjesztését. A felhasznált technológia az interoperabilitásnak természetesen csak az egyik metszetét képezi; a siker záloga elsốsorban az intézményi változás és az egyes adminisztrációs rendszerek közötti koordinációs folyamatok ösztönzése. Szükségszerű, hogy az e-kormányzat fejlesztésének központi magját az európai gazdasági növekedést elősegítő, az uniós állampolgárság fogalmának értelmet adó és az integrált múködés alapelvére épülő páneurópai szolgáltatások fejlesztése alkossa. Ezen a téren az úttörő kezdeményezések - például az EURES, a PLOTEUS és a SOLVIT ${ }^{3}$ portálok - alapvetốen azokat a hibákat küszöbölik ki, amelyeket az egyes nemzetállamok követnek el, amikor az adott ország hagyományait és a nemzeti prioritásokat állítják a középpontba, és más tagállamok állampolgárai számára nem nyújtanak teljes értékủ szolgáltatásokat.

Biztonságos e-kormányzat és azonositásmenedzsment. Az e-kormányzat sikeres megvalósítása elválaszthatatlan a bizalom kérdéskörétôl, attól, hogy az állampolgárok nyugodt szívvel, tömegesen használják a különbözô online szolgáltatásokat. Az állampolgári kereslet alacsony fokának másik oka a bizonytalansági tényezók nagy száma. Az Unió törekvései több területen is komoly korlátokba ütköznek. Az elektronikus közszolgáltatások minôségérôl és használati módjairól a 2003 novemberében készült, „Top of The Web” címú felmérés szerint (Survey on quality and usage of public e-service) a polgárok közel 80\%-a - biztonsági kockázatra hivatkozva - elzárkózik az online vásárlástól. Ez az arány a vállalkozói szférában $54 \% .{ }^{4} \mathrm{~A}$ biztonság kérdésköre szorosan ösz-

\footnotetext{
${ }^{3}$ Az EURES az „Európai Foglalkoztatási Mobilitás” elnevezésú program portálja, ami megkönnyíti az európai álláslehetôségekkel és tanulmányi lehetôségekkel kapcsolatos információk felkutatását (elérhetô a www.europa.eu.int/eures címen). A PLOTEUS portált az Európai Bizottság hozta létre az „Európai Tanulási Lehetôségek" kikötôjeként, ami segít eligazodni az európai oktatási és képzési lehetôségek között (elérhetổ a www.europa.eu.int/ploteus címen). A SOLVIT az egységes piacon érvényesíthetổ jogok gyüjteménye (elérhetố a www.europa.eu.int/solvit címen).

${ }^{4}$ Top of The Web. Survey on quality and usage of public e-services. November 2003.
} 
szefügg az azonosítás problémáival, az elektronikus aláírás rendszerének sikeres bevezetése tehát elengedhetetlen valamennyi tagállamban.

A kérdéskör másik vetülete a szélessávú hozzáférés biztosítása mind több állampolgár számára, ami az online tartalomszolgáltató piacok tömeges megjelenését hívja életre. Ezért az Unió egyre nagyobb figyelmet szentel a digitális jogok ügyének (Digital Rights Management, DRM).

A felhasználók elvárásai. Az állampolgárok elvárásai több pontban ragadhatók meg: transzparens, nyitott közszolgáltatást kívánnak, ami egyrészt személyre szabott módon, egyenlő bánásmódban részesít mindenkit, másrészt bármikor elszámoltatható. Az Unió érdeklődésének fókuszában annak vizsgálata áll, hogy a felhasználók hogyan értékelik a jelenleg múködő online szolgáltatásokat. A felmérések azt mutatják, hogy a használat terén további egyszerúsödésre van szükség, ugyanakkor az állampolgárok továbbra is azokat a szolgáltatásokat preferálják, amelyekkel idő́t takaríthatnak meg.

Az elektronikus demokrácia megvalósulása. Az IKT eszközeivel átitatott közszolgáltatás demokratizálódási folyamatok elindítását eredményezi, az állampolgárokhoz közelebb álló Unió megteremtésének ígéretét hordozza, és növeli a közös európai identitás kialakulásának történelmi esélyét. Az online demokrácia lényegéhez tartozik az is, hogy az állampolgárok minél szélesebb köre kapcsolódjék be az online alkalmazások világába. Így például a speciális igényú régiók vagy a hátrányos helyzetû́ polgárok számára a multi-platform és a vezetéknélküli (mobil) alkalmazások elterjedése, valamint a helyi sajátosságok figyelembevétele jelenthet segítséget abban, hogy részesei legyenek a folyamatoknak.

A fentiekben bemutatott trendek és irányelvek azt az üzenetet hordozzák, hogy a nemzetek fölötti szinten is rendeznie kell a sorokat, összehangolt akciók és egységes politikai állásfoglalások keretében síkraszállva a back office folyamatok centralizálása mellett. Az.e-kormányzat fejlesztése csak a felhasználók tömeges méretû bevonásával érhet el sikereket

\section{Az e-kormányzat fejlesztésének területei}

A prioritások felismerése, a meta-szint meghatározása és a helyzetértékelés nyomán az Európai Unió 2003-ban a „Az e-kormányzat szerepe Európa jövójében” (The Role of eGovernment for Europe's future) címú dokumentum megszövegezésével az alábbi feladatok végrehajtása mellett kötelezte el magát: ${ }^{5}$

1. okcsatornás hozzáférési lehetőségek biztosítása a közszolgáltatások online igénybevételéhez,

2. új szolgáltatások beindítása nagy sávszélességủ hálózatokon keresztül,

3. a bizalom és a megbízhatóság növelése,

4. a közszféra dokumentumainak újrahasznosítására vonatkozó direktívák adaptálása,

5. az elektronikus közbeszerzés támogatása,

6. páneurópai szolgáltatások kiépítése,

7. az interoperabilitás keretrendszereinek adoptálása,

\footnotetext{
${ }^{5}$ Pintér Róbert: E-kormányzat az Európai Unióban: irányváltás és gyorsítás. MEH EKK „E-kormányzat elsổ kézbôl", 2004. január 27.
} 
8. az alappontok és az egyes szintek megállapításához (benchmarking) új megközelítési módok kialakítása,

9. az egyablakos e-kormányzati szolgáltatások kiépítésének támogatása.

Az eEurope program végrehajtásának sikere az elmúlt években megkérdőjeleződött. Ez az Unió döntéshozóit újabb akciók és konkrét cselekvési tervek kidolgozására késztette, amelyek szoros összhangban állnak a megteendô lépéseknek általános keretet adó stratégiával. Az e-kormányzati fejlesztési törekvések sikere részben ${ }^{6}$ a fenti akciók feltétel nélküli végrehajtásától függ, hiszen ennek hiányában az információs társadalom nemzetek fölötti szinten történô építésének lehetôsége is megkérdôjeleződhet.

\section{A sikeres megvalósítás tényezői}

Az e-kormányzati szolgáltatások megvalósításának sikere elsősorban az állampolgárok érdeklődésétől és a szolgáltatások fejlettségi szintjétől függ. A felhasználók tevékenységeit az online közszolgáltatásokkal kapcsolatban a Taylor Nelson Sofres (TNS) nemzetközi piackutató vállalat elemzései mutatják be, míg a szolgáltatói oldal fejlettségét a Cap Gemini Ernst \&̊ Young nemzetközi gazdasági tanácsadó cég jelentései tükrözik. Az elemzések alapján meghatározható mélyebb összefüggések és trendek felvázolásakor óvatosan kell eljárni, ugyanis egymásnak ellentmondó kutatási eredmények születtek.

A TNS felmérése szerint az Európai Unió országaiban évről évre egyre többen veszik igénybe az elektronikus kormányzati szolgáltatásokat. Hagyományosan az északi országok mutatják fel a legnagyobb növekedést: az online közigazgatási szolgáltatások iránti állampolgári kereslet 2003-ban Hollandiában 41 százalékról 52 százalékra, Finnországban pedig 49 százalékról 58 százalékra növekedett. ${ }^{7}$ Az Interneten keresztül elérhető kormányzati szolgáltatásokat Dániában veszik a legtöbben igénybe, számuk a lakosságnak mintegy 63 százalékát teszi ki. A felhasználók többsége ugyan továbbra is információkeresésre használja a kormányzati honlapokat, a korábbi évekhez képest mégis az interaktív szolgáltatások terén tapasztalható a legnagyobb növekedés: ezek igénybevételének aránya 1 százalékról 8 százalékra emelkedett. A biztonság kérdését illetôen már nincs ilyen kedvezô változás: azoknak a százalékos aránya, akik az online közszolgáltatást biztonságosnak tartják, mindössze 2 százalékponttal növekedett.

Az Európai Unió legfóbb tennivalója tehát továbbra is az állampolgárok biztonságérzetének növelése, a kételkedők meggyốzése és a lakosság ösztönzése az új eszközök használatára, tagállami és nemzetek fölötti szinten egyaránt.

A Cap Gemini jelentésében foglalt információk értékelésének alapját az Európai Bizottság által kidolgozott négyszintû rendszer képezi: ${ }^{8}$

\footnotetext{
${ }^{6}$ Emellett azonban minden államnak meghatározó szerepre kell törekednie a nemzetek fölötti szinten létrejövổ információs társadalomról szóló diskurzusban, amit úgy érhet el, ha az információs társadalom megvalósításához tartozó valamely részterületet mesteri szinten mûvel.

${ }^{7}$ Taylor Nelson Sofres (2003): Government Online. An international perspective - annual global report 2003 (http://www.tns-global.hu/pic/GO2003_GlobalReport.ppt )

${ }^{8}$ Pintér Róbert, Juhász Lilla, Tarr Ágnes: E-kormányzat az Európai Unió tagállamaiban. Zárótanulmány. Infonia Alapítvány, 2003.
} 
- Első szint: Információ - online megtalálhatók az ügyintézés elindításához szükséges háttérinformációk.

- Második szint: Egyirányú kommunikáció - az ügyintézéshez szükséges formanyomtatványok az illetékes intézmény honlapjáról letölthetôk vagy online megrendelhetốk, de elektronikus formában nem küldhetốk vissza.

- Harmadik szint: Kétirányú kommunikáció (interaktivitás) - a nyilvánosan hozzáférhetố webkikötô online kitölthetô hivatalos formanyomtatványokat tartalmaz. Ez egyúttal azt is jelenti, hogy a hitelesítés problémája megoldott.

- Negyedik szint: Teljes körû́ elektronikus esetkezelés - a nyilvánosan hozzáférhetô webkikötő segítségével az ügyek mindvégig elektronikus formában intézhetôk, beleértve a döntéshozatalt és az ügyfelek kiértesítését is. Az ügyintézés nem igényel papírmunkát.

Ez a felmérés - a TNS kutatás eredményeivel ellentétben - arra világít rá, hogy az Európai Unió tagállamaiban a legutóbbi években megtorpant az e-kormányzati aktivitás, lelassult az világhálón keresztül igénybe vehető szolgáltatások kiépítése. Az online kormányzati tevékenység kifinomultsági szintje a vizsgált időszakban mindöszsze 7 százalékponttal emelkedett, ami megdöbbentôen csekély mértékủ növekedést jelent. A kétoldalú kommunikáció szintjén azonban jelentôs változások történtek: a tagállamok többségének sikerült elérnie az online kormányzati szolgáltatások fejlettségének ezt a szintjét. A vizsgált országok közül a legkiemelkedőbb fejlődést Ausztria produkálta, felzárkózva az északi országokhoz. Továbbra is érvényes az a trend, hogy az üzleti szektor számára kínált szolgáltatások fejlettségi szintje jóval magasabb, mint az állampolgárok számára elérhetôké. A Cap Gemini által végzett kutatás csak a világhálón elérhetố front office szolgáltatások vizsgálatára korlátozódott, a back office szolgáltatásokra nem terjedt ki. Ennek ellenére ez is jól tükrözi, hogy az e-kormányzat fejlesztésének központi magvát továbbra is az állampolgárbarát rendszerek építése képezi. ${ }^{9}$

\section{Sikeres e-kormányzati fejlődési utak a régi és új tagállamokban}

A fenti vizsgálatok - bár eredményeikból csak korlátozott mértékig lehet következtetéseket levonni - egyértelműen kimutatják, hogy az e-kormányzati szolgáltatások fejlesztése terén továbbra is az északi országok játszanak vezető szerepet. Az alábbiakban az online közszolgáltatások sikeres fejlesztésének lehetséges útját kívánom bemutatni a skandináv országok példáján keresztül, a fejlődésre ható okok vizsgálatának segítségével. A kutatások azt mutatják, hogy ebben a folyamatban a politikai, társadalmi és gazdasági tényezốk összjátékára van szükség, ez tekinthetố az e-kormányzati siker előfeltételének. A fejlesztési törekvéseknek valamennyi vizsgált ország esetében a politikai elit konszenzusán nyugvó és a tágabb értelemben vett politikai diskurzusba beágyazódott nemzeti stratégia ad szilárd kereteket. Az információs társadalom kihí-

9 European Commission DG Information Society: Cap Gemini Ernst \& Young's Online Availability of public services: How is Europe progressing? Web based survey on electronic public services. Report of the fourth measuremant, October 2003

(http://europa.eu.int/information_society/eeurope/2005/doc/highlights/whats_new/capgemini4.pdf) 
vásai a technológiai innováción túl megkövetelik a tudomány, a gazdaság és a civil szféra együttmúködését, valamint az úgynevezett „gördülố tervezésre” épülő és a helyi sajátosságokat figyelembe vevő stratégiák kidolgozását és követését. A mindenkori politikai tervezésnél figyelembe kell venni a digitális fejlesztés kihívásait, a társadalmi és ágazati elvárásokat és a döntéshozók politikai elkötelezettségét. Fontos szempont továbbá az infrastruktúra, az emberi erőforrások fejlesztése, valamint az informatikai ipar és az „alkalmazási világok” fejlesztése is. A társadalmi tényezők közül az innovációra és a modernizációra nyitott állampolgári attitúd és a homogén politikai kultúra viheti sikerre az e-kormányzati fejlesztési programokat. Az említett felmérésekben vizsgált országokat kivétel nélkül a gazdasági prosperitás jellemzi, ami lehetőséget ad a jó eszközellátásra és a legmegfelelốbb technológiai vívmányok használatára.

A frissen csatlakozó uniós tagállamok közül a balti államok e-kormányzati aktivitása mutat figyelemre méltó fejlődést. Ezek az országok földrajzilag közel fekszenek a skandináv államokhoz, s emellett kulturális sajátosságaik is hasonlóak azokéihoz. A siker záloga azonban itt is abban a felismerésben rejlik, ami a politikai elitet és a társadalmat egyaránt áthatja: a kis országoknak az információs társadalom és az e-kormányzat kiépítése terén kizárólag a hosszú távon érvényesülő, progresszív társadalmi konszenzus és az elektronikus szolgáltatások prioritása mellett elkötelezett politika adhatja meg a kiugrási lehetôséget.

\section{Zárszó: Európa és Magyarország esélyei}

A huszonegyedik század hajnalán Magyarország fejlődési útját egy 25 tagállamból álló konglomerátum határozza meg, amely grandiózus terveket sző a világban betöltött vezető szerep megszerzésére. Az elektronikus kormányzati aktivitás terén mutatkozó csökkenő ütemú fejlődés Európa döntéshozóit az eddigi irányvonal átértékelésére késztette. Az elektronikus ügyintézés megvalósításában a tagállamok között tapasztalható különbségek a nemzetek fölötti politika eróit arra sarkallják, hogy a széttöredezettség helyett egységes politikai állásfoglalások és konkrét programok végrehajtása mellett szálljanak síkra. Kérdés azonban, hogy sikerül-e a saját kultúrával, identitással, ezeréves gyökerekkel és hagyományokkal rendelkező nemzetállamokat elkötelezetté tenni az információs társadalom ügye mellett. Egyelőre úgy tủnik, hogy az információs és kommunikációs technológiákkal átitatott tudástársadalom mint legfőbb prioritás fontosságát az északi, kulturális beállítódásukat tekintve a modernizációra és a technológiai innovációra nyitott államok értették meg a legjobban, ami hosszú távon az európai erőviszonyok javukra történő átrendeződését is eredményezheti.

Az európai modell első és legfontosabb lépésként az online közigazgatás megteremtését, a back office folyamatok reformját, centralizációját és egy „emberarcú” közigazgatás megteremtését tüzi ki célul. Számunkra az a legfontosabb kérdés, hogy Magyarország képes lesz-e felismerni a fejlődés irányát: a félperifériáról centrális pozícióba tud-e kerülni, és kíván-e az e téren folyó diskurzus egyik meghatározó szereplőjévé válni, vagy továbbra is megelégszik - a fent bemutatott általános irányelvek szükségszerú követésén túl - a brüsszeli direktívák adaptálásával és más országok gyakorlatának egyszerû́ másolásával. 


\section{IRODALOM}

Alabau, Antonio (2003): Understanding the e-Government Policy of the European Union. A comparative analysis with the e-Government policies of some supra national Organizations. Working Document, Reference: PTSI/24. Universidad de Valencia (http://www.eurocities.org/eurocities/Documents/eGov.Alabau.PDF )

Council of the European Union: Legislative Acts And Other Instruments, Brussels, 28 January 2004

European Commission: „The Role of eGovernment for Europe's future”

(http://europa.eu.int/information_society/eeurope/2005/doc/all_about /egov_communication_en.pdf)

eGovernment Research Advisory Workshop, 2003. december 8.

eGovernment Research \& Development (http://europa.eu.int/information_society/programmes/egov_rd/focus/index_en.htm)

eEurope 2005 Mid-term Review (http://www.europa.eu.int/information_society/eeurope/2005/all_about/mid_term_review/index_en.htm )

European Commission DG Information Society: Cap Gemini Ernst \& Young's Online Avalability of public serviceses: How is Europe progressing? Web based survey on electronic public services. Report of the fourth measuremant, October 2003

(http://europa.eu.int/information_society/eeurope/2005/doc/highlights/whats_new/ capgemini4.pdf)

European Ministerial Conference on the information society: New opportunities for growth in an enlarged Europe, Conference Conclusions, Budapest, February, 2004

European eGovernment Conference: Ministerial Declaration, Como, 2003, July 7-8. eEurope2003 progress report, 2004 February

Online Availability of Public Services: How is Europe Progressing? Web Based Survey on Electronic Public Services. Report of the 4th Measurement October 2003. Prepared by Cap Gemini Ernst \& Young for European Commission DG Information Society. January 2004

http://europa.eu.int/information_society/eeurope/2005/doc/highlights/whats_new/capg emini4.pdf

Paul Timmers: eGovernment Policy and the EU, Public Administrations Conference, Naples Italy, 22 November 2003

Paul Timmers: eGovernment Parallel Session I, EISCO 2003, Aalborg Denmark, 19 November 2003

Pintér Róbert: E-kormányzat az Európai Unióban: irányváltás és gyorsítás. MEH EKK „Ekormányzat elsố kézból”, 2004. január 27.

Pintér Róbert - Juhász Lilla - Tarr Ágnes: E-kormányzat az Európai Unió tagállamaiban. Zárótanulmány. Infonia Alapítvány, 2003, július

Taylor Nelson Sofres (2003): Government Online. An international perspective - annual global report 2003

(http://www.tns-global.hu/pic/GO2003_GlobalReport.ppt ) 
The Role of e-Government for Europe's Future. COMMUNICATION FROM THE COMMISSION TO THE COUNCIL, THE EUROPEAN PARLIAMENT, THE EUROPEAN ECONOMIC AND SOCIAL COMMITTEE AND THE COMMITTEE OF THE REGIONS. Brussels, 26.9.2003 http://www.europa.eu.int/information_society/eeurope/2005/doc/all_about/egov_ communication_en.pdf

Top of The Web. Survey on quality and usage of public e-services. November 2003.

http://europa.eu.int/information_society/eeurope/2005/doc/all_about/quality_usa ge_final_report_2003.pdf 